\title{
ANTHROPOGENIC INFLUENCES ON THE URANIUM CONCENTRATION IN WATERS OF THE CORUMBATAI RIVER BASIN (SP), BRAZIL
}

\section{FABIANO TOMAZINI DA CONCEICAO \& DANIEL MARCOS BONOTTO}

\begin{abstract}
This study reports the anthropogenic influences on the uranium concentration in the waters of the Corumbatai river basin (SP), which can affect the U-isotopes modeling used to evaluate the weathering rate of the rocks. The studied waters are generally neutral, with phosphate contents of up to about $3 \mathrm{mg} / \mathrm{L}$. The uranium concentration increases with increasing flow and phosphate content, in accordance with the expected complexation of uranyl ion under the observed $\mathrm{pH}$ values. The relationship between dissolved uranium and discharge is opposite of that already referred to in the literature, being certainly affected by the continuous use of fertilizers in sugar cane crops, since they are generally enriched in radionuclides.
\end{abstract}

Keywords: uranium, phosphate, fertilizer, weathering rate

INTRODUCTION Freshwaters comprise about 3\% of the total amount of water in nature, where $97 \%$ is found in oceans and salty seas. Almost $2.3 \%$ of freshwater is located in glaciers, ice caps or deep aquifers (Porto et al. 1991). Consequently, in the present days this important resource has been much protected against activities that may affect its quality.

The nuclear techniques are useful to study and solve problems related to hydrological resources (IAEA 1991). The natural uranium comprises the isotopes ${ }^{238} \mathrm{U},{ }^{234} \mathrm{U}$ and ${ }^{235} \mathrm{U}$, that have the same geochemical behavior and whole relative proportions, under radioactive equilibrium conditions, of $99.28 \%, 0.0054 \%$ and $0.72 \%$, respectively (Cowart \& Osmond 1974). ${ }^{234} \mathrm{U}$ is radiogenic, being generated in the ${ }^{238} \mathrm{U}$ decay series after one alpha decay and two beta decays. This isotope is responsible for the production of two intermediate nuclides with short half lives, i. e., ${ }^{234} \mathrm{Th}$ (24.1 days) and ${ }^{234} \mathrm{~Pa}$ (1.18 minutes).

${ }^{234} \mathrm{U}$ is preferentially mobilized in relation to ${ }^{238} \mathrm{U}$ in the course of rock weathering. Measurements of the ${ }^{234} U{ }^{238} U$ activity ratio in rocks, soils and waters, has been used to calculate the uranium fraction dissolved during weathering (solution coefficient for uranium) and to evaluate the weathering rate of rocks (Moreira-Nordemann 1979).

In this paper, the ${ }^{238} \mathrm{U}$ concentration and the ${ }^{234} \mathrm{U}^{238} \mathrm{U}$ activity ratio (AR) were determined for freshwaters of the Corumbatai river basin. The results were used to studs how anthropogenic activities affect the concentration of dissolved uranium, and consequently, the U-isotopes modeling that dependents on this parameter.

PHYSIOGRAPHIC FEATURES The Corumbatai River and tributaries (Claro stream, Passa Cinco River and Cabeças river) extend over an area of about $1,581 \mathrm{~km}^{2}$ in the middle-east part of the São Paulo State (Fig. 1). It occurs as an eroded belt in the cuesta zone of the DepresSão Periferica geomorphological province (Penteado 1976). Such province delimits the northeastern edge of the basaltic flows in the Parana sedimentary basin and the crystalline plateau, being submitted to smooth processes during the past geological time.

The Corumbatai River and affluents start flowing in the cuesta zone, reaching Piracicaba River after crossing Rio Claro City, the most important municipality in the basin. The average monthly flow rate in the last 25 years was $26.45 \mathrm{mV}$, with a maximum value of 168.36 $\mathrm{mV}$ (February 1995) and a minimum value of $5.96 \mathrm{mV}^{1}$ (September 1994) (Conceição \& Bonotto 1999). The climate of the region is Aw type (Koeppen classification), i. e., tropical rainy weather characterized by wet summer (October through March) and dry winter (April through September) (Inacio \& Santos 1988). The area often has 55 65 days of rain per year, with more than $80 \%$ of the precipitation falling between October through March (Bonotto \& Mancini 1992).

Several stratigraphic units of the Parana sedimentary basin (Paleozoic - Cenozoic) crop-out in the Corumbatai river basin (IPT 1981): Itarare Subgroup (sandstones, conglomerates, diamictites, tillites, siltstones, shales and rhythmites) and Tatui Formation (siltstones, shales, silex and sandstones with local concretions) from Tubarao Group; Irati Formation (siltstones, mudstones, dark bituminous shales and limestones) and Corumbatai Formation (mudstones, shales and siltstones) from Passa Dois Group; Piramboia Formation (sandstones, shales and muddy sandstones), Botucatu Formation (sandstones and muddy sandstones), Serra Geral Formation (basalt and diabase) and related basic intrusives from São Bento

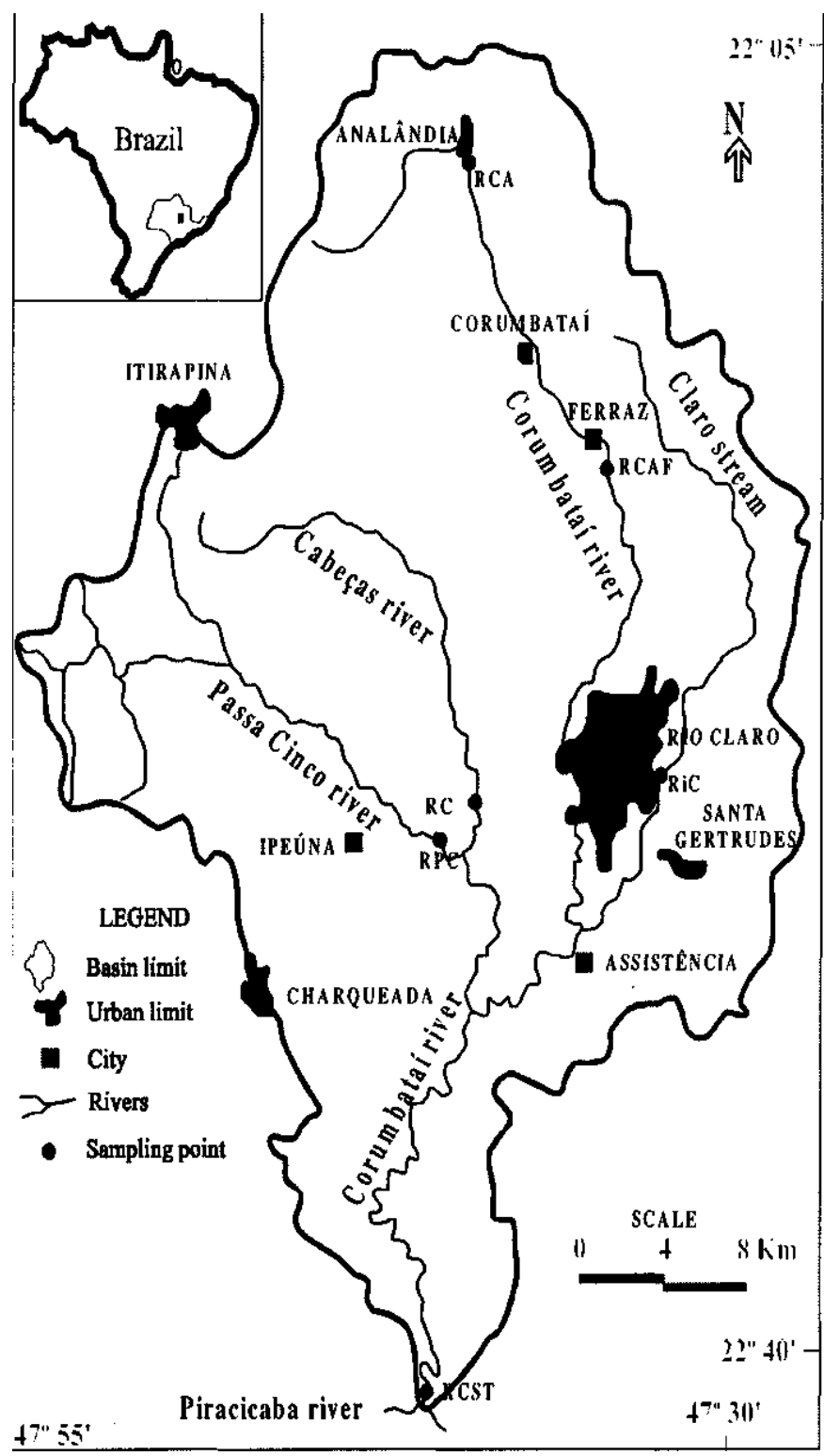

Figure 1 - The Corumbatai river basin and location of the sampling points $R C A$ - Corumbatai river (Analdndia); $R C$ - Cabecas river; $R F C$ - Passa Cinco river; RCAF - Corumbatai river (Ajapi-Ferraz); RCST - Corumbataí river (Santa Terezinha); RiC-Claro Stream.

Group; different types of Cenozoic covers like the Rio Claro Formation (sandstones, conglomerate sandstones and muddy sandstones), recent deposits and terrace sediments. Among the major types of soils occurring in the Corumbatai river basin, red-yellow 
podzols and latossoils cover about $65 \%$ of the area of the basin (Koffler 1993).

SAMPLING AND METHODS The water samples from Corumbatai River and tributaries were collected for hydrochemical and U-isotope analyses between 08/13/1998 and 01/20/1999 at the sampling points shown in Fig. 1. Samples from each site were divided in three aliquots and stored in polyethylene bottles under different conditions: unfiltered and non-preserved (samples were used for dissolved oxygen, conductivity and dry residue measurements); Filtered with $0.45 \mathrm{~mm}$ Millipore membrane and non-preserved (samples were used for alkalinity and chloride determinations); Filtered with $0.45 \mathrm{~mm}$ Millipore membrane and preserved with $\mathrm{HNO}_{3}$. (samples were used for major ions and uranium determinations). All the samples were analyzed in terms of physical parameters $(\mathrm{pH}$, dissolved oxygen, conductivity and dry residue) and principal dissolved cations and anions.

The major cations $\mathrm{Na}$ and $\mathrm{K}$ were analyzed by Atomic Absorption Spectroscopy (AAS) and $\mathrm{Ca}$ and $\mathrm{Mg}$ by Inductively-Coupled Plasma Atomic Emission Spectrometers (ICP-AES) at two laboratories: LABOGEO (Laboratory of Geochemistry), Department of Petrology and Metallogeny, Institute of Geosciences and Exacts Sciences - Universidade Estadual Paulista "Julio de Mesquita Filho" (UNESP) - Rio Claro; Laboratory of Analytical Chemistry, Center for Nuclear Energy in Agriculture (CENA) - Escola Superior de Agronomia Luiz de Queiroz (ESALQ) - Universidade de São Paulo (USP) - Piracicaba.

Sulfate, phosphate, alkalinity and nitrate were measured by a Hach DR 2000 spectrophotometer from the Laboratory of Isotopes and Hydrochemistry (LABIDRO), Department of Petrology and Metallogeny. Chloride was evaluated by potentiometry at LABIDRO, according to the procedure described by Tonetto (1996). Dissolved oxygen was measured in the field, whereas $\mathrm{pH}$ and conductivity were measured at LABIDRO not more than 6 hours after sampling.

The evaluation of the dissolved uranium was performed using standard alpha spectrometric techniques (Bonotto 1982). After filtering the sample through $0.45 \mathrm{~mm}$ membrane, a known amount of ${ }^{232} \mathrm{U}$ spike $(3.39 \pm 0.15 \mathrm{dpm})$ was added. The uranium was co-precipitated with $\mathrm{Fe}(\mathrm{OH})_{3}$, iron was extracted with isopropyl ether, and U separated from $\mathrm{Th}$ and other elements by anion exchange resin (Rexyn 201). The aliquot containing $U$ was transferred to an electrodeposition cell, and $\mathrm{U}$ was deposited on a stainless steel plate after 3 hours at a current density of $1 \mathrm{Acm}^{-2}$. The $U$ concentration and ${ }^{234} \mathrm{U} /{ }^{238} \mathrm{U}$ activity ratio (AR) were evaluated by alpha spectrometry using a $\mathrm{Si}(\mathrm{Au})$ surface barrier detector. The dissolved uranium was calculated by isotope dilution from the counting rates of ${ }^{238} \mathrm{U}$ and ${ }^{232} \mathrm{U}$ peaks and AR was calculated from the counting rates of ${ }^{238} \mathrm{U}$ and ${ }^{254} \mathrm{U}$ peaks. Table 1 shows the results obtained in this investigation.

DISCUSSION AND CONCLUSIONS The water $\mathrm{pH}$ values obtained in all sampling sites from Corumbatai river basin are close to neutral. The highest conductivity values were always found at Santa Terezinha site, where the Corumbatai river receives the contribution of the tributaries, besides of domestic and industrial wastes mainly from

Table 1 - Physical and chemical parameters for waters of the Corumbatai river basin.

\begin{tabular}{|c|c|c|c|c|c|c|c|c|c|c|c|c|}
\hline Paratameters & Un't & $\begin{array}{c}\mathrm{RCST} \\
1\end{array}$ & $\begin{array}{c}\text { MCST } \\
2\end{array}$ & $\begin{array}{c}\text { SCST } \\
3\end{array}$ & $\begin{array}{c}\mathrm{KCST} \\
4\end{array}$ & $\begin{array}{c}\text { MCST } \\
5\end{array}$ & \begin{tabular}{|c|} 
MCSTT \\
6
\end{tabular} & $\begin{array}{c}\text { RCA } \\
1\end{array}$ & $\begin{array}{c}\mathbf{K} C A F \\
1\end{array}$ & $\begin{array}{c}\mathbf{R P C}^{+} \\
\end{array}$ & $\begin{array}{c}\mathrm{RC} \\
\mathbf{1}\end{array}$ & $\begin{array}{c}\text { RiC } \\
1\end{array}$ \\
\hline Discluwger & $\mathrm{m} \mathbf{m} / \mathrm{s}$ & 13.33 & 15.05 & 15.48 & 12.40 & 26,23 & 49.71 & & & & & \\
\hline Coxductivity & uStcm & $\begin{array}{r}6.7 \\
284.4\end{array}$ & $\begin{array}{l}6.8 \\
170.7\end{array}$ & $\begin{array}{c}73 \\
2080\end{array}$ & $\begin{array}{l}6.5 \\
2060\end{array}$ & $\begin{array}{c}6.8 \\
1794.8\end{array}$ & $\begin{array}{c}69 \\
182.8\end{array}$ & $\begin{array}{l}6.8 \\
48.3\end{array}$ & $\begin{array}{c}70 \\
48.7\end{array}$ & $\begin{array}{l}64 \\
99.2\end{array}$ & $\begin{array}{l}6.4 \\
52.6\end{array}$ & $\begin{array}{c}70 \\
65.5\end{array}$ \\
\hline $\begin{array}{c}\text { Dissolved } \\
\text { Oxigen }\end{array}$ & $\mathrm{mg} \mathrm{g} / \mathrm{L}$ & 6.7 & 6.9 & 13 & 6.5 & 7.3 & 6.8 & 7.7 & 7.5 & 7.8 & 7.8 & 7.7 \\
\hline Dry ressidue & $m g / L$ & 191 & 127 & 154 & 195 & $2: 17$ & 172 & $n$ & 97 & 37 & 75 & 80 \\
\hline $\mathrm{N}_{*}$ & $\mathrm{mg} / \mathrm{L}$ & 600 & 7.56 & 8.34 & 10.71 & 6.97 & 6.19 & 1.53 & 1,50 & 3.31 & 1,76 & 2.36 \\
\hline $\mathrm{C}$ & $m g h$ & 2500 & 18,58 & 17.68 & 16,39 & 16,74 & 1204 & 9.10 & 10.50 & 11.90 & 10.40 & 12.10 \\
\hline $\mathrm{K}$ & $\mathrm{mgh}$ & 8.72 & 4.16 & 3.55 & 4,65 & 2,89 & 2.16 & 1.51 & 1.21 & 1.71 & 1.117 & 1.19 \\
\hline & & 600 & 5.51 & 6.71 & 4,72 & 6,61 & 6,77 & 0.80 & 1,30 & 3,40 & I.fin & 1.90 \\
\hline $\mathrm{SO}_{4}$ & $m g \mathrm{IL}$ & 17 & 48 & 44 & 21 & 32 & 37 & 0 & j & 4 & 0 & 0 \\
\hline $\mathrm{No})_{i}^{-}$ & moll & 9.24 & $10.5 \%$ & 8.36 & 13.54 & 13.20 & 9.24 & 5.72 & $5.2 \mathrm{~K}$ & $3 \%$ & 1.52 & 4.40 \\
\hline c & $\operatorname{lng} 2$ & 1.08 & 4.45 & 4. $[1]$ & $6.1 \mathrm{n}$ & $4.4 \pi$ & 3.80 & 1.22 & $1.0 x$ & 1.22 & 1.22 & 1.69 \\
\hline $\mathrm{HCO}_{3}^{-}$ & $\operatorname{ingh}$ & 4) & wo & 3) & 30 & 25 & 26 & 8 & 8 & 14 & 16 & 16 \\
\hline $\mathrm{PO}_{4}^{\mathrm{I}}$ & Imgh & ff. 15 & 0.96 & 0.58 & f..1.3 & n.8* & 2.72 & 0.04 & 0.04 & $00 \%$ & 0,02 & 007 \\
\hline & ugh & 0.05 & 0.04 & 0.08 & 0.15 & 0.27 & 0.48 & 0.03 & & 0,44 & 0.22 & 0,02 \\
\hline${ }^{216} \mathrm{U}^{2} \mathrm{~s} \mathrm{U}$ & $A R$ & 1.81 & 2,64 & 1.84 & 1.98 & 1.71 & 1.54 & 3.36 & & 2.28 & 1.58 & 4.33 \\
\hline
\end{tabular}

the Rio Claro city. These wastes cause an enhancement on the conductivity and dry residue values, and contents of dissolved cations and anions. The dissolved oxygen at Santa Terezinha is slightly lower than at other sites, probably due to consumption of this element during decomposition (oxidation) of the abundant organic matter.

Calcium, potassium and bicarbonate concentrations at Santa Terezinha site tend to decrease with the increase of the discharge, suggesting a dilution of these ions due to seasonal effects. However, other major ions like sodium, magnesium, nitrate, chloride and sulfate don't exhibit the same trend, implying that the removal of the constituents by the drainage is not uniform along the basin, i. e., dissolution/adsorption may affect the ions in different ways, so that further studies are necessary to understand the variability.

According to CONAMA $\mathrm{N}_{0} 20$ (National Register for freshwaters, published in 18 June 1986), the results obtained for the major anions suggest that the analyzed waters belong to class 2 . However, in terms of phosphate, all the samples exhibited values higher than the maximum permissible concentration limit for freshwaters belonging to class $2(0.025 \mathrm{mg} / \mathrm{L})$, whereas, at Santa Terezinha site, the values for nitrate were practically the same of the maximum permissible concentration limit $(10 \mathrm{mg} / \mathrm{L})$.

Considering that the region is characterized by the presence of sedimentary rocks (IPT 1981), there is a limited availability of natural phosphorous and nitrogen in the area. On the other hand, phosphorous has been introduced in the area as related to sugar cane crops (Conceicao et al. 1999). The input of phosphorous fertilizer in the environment is the major factor responsible for the eutrophy process (increase of the concentration of nutrient in aquatic ecosystems), causing an increment of algae or other aquatic plants in reservoirs or stagnant waters.

The dissolved uranium concentration at Santa Terezinha site increased progressively from August $1998(0.05 \mu \mathrm{g} / \mathrm{L})$ to January 1999 $(0.48 \mathrm{Ug} / \mathrm{L})$. Except for November 1998, the discharge of the Corumbatai river basin in the same site increased from $13.33 \mathrm{mV}$ to $41.71 \mathrm{mV}^{1}$. These data indicate a significant correlation coefficient of 0.96 between the uranium concentration and river discharge (Fig. 2a). The samples collected at Claro stream and Corumbatai river (Analandia site) exhibited lower U content than those from Passa Cinco river and Cabecas river.

The average ${ }^{234} \mathrm{U}^{238} \mathrm{U}$ activity ratio for dissolved uranium in the waters from Corumbatai river (Santa Terezinha site) corresponds to 1.92 , suggesting the occurrence of preferential leaching of ${ }^{234} U$ relative to ${ }^{238} \mathrm{U}$, a process extensively discussed by Dooley et al, (1966; apud Bonotto 1996). A higher preferential leaching of ${ }^{234} U$ relative to ${ }^{238} \mathrm{U}$ was also observed for the waters of Claro stream and Corumbatai' river (Analandia site), whereas the AR's values obtained for the samples collected at Passa Cinco river and Cabeças river are similar to those found at Santa Terezinha site.

The most important uranyl complexes are formed with fluoride, phosphate and carbonate under acid, near neutral and alkaline conditions, respectively (Langmuir 1978). In order to evaluate this possibility at the studied area, statistical tests involving the dissolved uranium and the analyzed anions were performed for the samples from Santa Terezinha site, which allowed to find a significant correlation between dissolved uranium and phosphate $(\mathrm{r}=0.84)$ (Fig. 2b). Therefore, it was also possible to find a significant correlation between phosphate and discharge $(\mathrm{r}=0.94)$, as shown in Fig. 2c.

Thus, the obtained results confirm that the presence of dissolved phosphate affect the migration of uranium to the waters of the Corumbatai river basin, implying that the uranyl ions must be forming complexes with phosphate, situation favored by their near-neutral conditions.

Sugar cane is extensively cultivated at the Corumbatai river basin by industries that produce alcohol and sugar. Fertilizers are widely used in agriculture, particularly in tropical regions, where weathering of soil nutrients is more intense. The most used fertilizers in the Corumbatai' river basin are the simple or concentrated (triple) superphosphates $\left(20-42 \% \mathrm{P}_{2} \mathrm{O}_{5}\right)(\mathrm{CAC} 1991)$. In general, the cultivation of the sugar cane starts in September/October, when are applied about $600 \mathrm{Kg} /$ ha of fertilizers (CAC 1991). The phosphate 

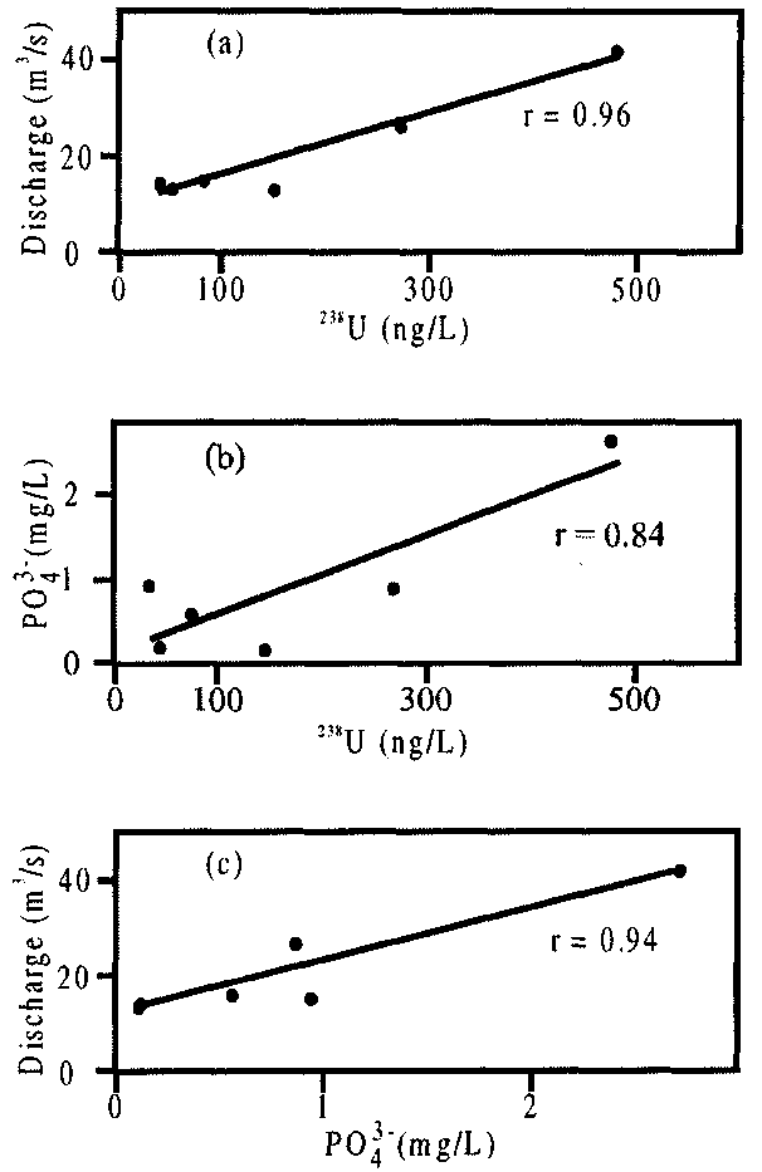

Figure 2 - The relationship between (a) discharge and dissolved uranium, (b) phosphate and dissolved uranium, and (c) discharge and phosphate in the waters of Corumbatai river sampled at Santa Terezinha. rocks contain radionuclides and other elements/compounds, including uranium.

The presence of phosphate in waters of the Corumbatí river basin was initially recognized by Palma-Silva (1999), who attributed phosphate content to residential and industrial wastes discharged at Rio Claro urban area. The presence of radionuclides in fertilizers utilized in the Araras region, close to the Corumbati river basin, was also reported by Ferreira et al. (1997). The significant correlation between dissolved uranium and phosphate $(\mathrm{r}=0.84)$, discharge and phosphate $(\mathrm{r}=0.94)$ and discharge and dissolved uranium $(\mathrm{r}=0.96)$ suggest that the Corumbatai river must be receiving (from laminar erosion) large quantities of radionuclides, which are associated to phosphate fertilizers that are extensively used in agrochemical activities. The higher concentrations are more pronounced during the wet periods when the fertilizers, natural uranium and uranium in fertilizers are released from the soil cover. The presence of $U$ and other elements generated by the radioactive decay in fertilizers derived from phosphate rocks may conduct to their redistribution in the environment due to agricultural activities, causing an enhancement of the natural gamma radiation emitted by the soils.

Non-natural inputs of uranium isotopes ${ }^{238} \mathrm{U}$ and ${ }^{234} \mathrm{U}$ in the drainage due to agrochemical activities greatly affect the U-isotopes modeling for evaluating the weathering rate of rocks, since the equations needed for the calculations (Moreira-Nordemann 1979) are dependent of the concentration of dissolved uranium and ${ }^{234} \mathrm{U} /{ }^{238} \mathrm{U}$ activity ratio of dissolved uranium. The preferential release of ${ }^{234} U$ to the liquid phase is sustained during water-rock/soil/fertilizer interactions, and, thus, the AR values don't affect the evaluation of the weathering rate on the Corumbataí river basin. However, it is very important the choice of the value of the dissolved uranium concentration, because variations of up to 7 times may occur on the weathering rate in this basin.

Acknowledgements This investigation was performed under a scholarship from FAPESP, Brazil. To Mr. Eneas Antonio Ferguson of the Agricultural House of Rio Claro for access to local informations. To two anonymous referees of RBG for reviewing the manuscript.

\section{References}

Bonotto D. M. 1982. Aplicação dos dados do fracionamento isotopico U234/U238 nos problemas geoquímicos dos aquifems de dguas da prata (SP). Institute Astronômico e Geofísico, Universidade de São Paulo, São Paulo, Dissertação de Mestrado, $161 \mathrm{p}_{238}$

Bonotto D.M. 1996. Comportamento hidrogeoquímico do do ${ }^{222} R n$ e isotopos de urânio ${ }^{238} U$ $e^{234}$ U sob condiçốes controladas de laboratório e em sistemas naturals. Institute de Geociências e Ciencias Exatas, Universidade Estadual Paulista, Rio Claro, Tese de Livre Docência, 223p.

Bonotto D.M. \& Mancini L.H. 1992. Estudo hidroquimico e isotópico dos aquiferos de Rio Claro (SP). Geochim. BrasiL, 6:153-167.

CAC (COOPERATIVA AGRICOLA COTIA) 1991. Manual de adubação e calagem. $1 \mathrm{ed}$ São Paulo, 56p.

Conceifao FT., Lima J.L.N., Bonotto D. M. 1999. Hidroquímica elementar na bacia do Rio Corumbatai (SP). In: V Congresso de Geoquímica dos Pafses de Lingua Portuguesa \& VII Congresso Brasileiro de Geoquímica. Porto Seguro, Bahia, Anais, pp. 72 74.

Cconcei9ao FT. \& Bonotto D. M. 1999. Estudo do intemperismo na bacia do Rio Corumbatai (SP) pelo metodo do desequilíbrio isotopico do uranio. V Congresso de Geoqufmica dos Pafses de Lingua Portuguesa \& VII Congresso Brasileiro de Geoqufmica. Porto Seguro, Bahia, Anais, pp. 315-317.

Conselho Nacional do Meio Ambiente. 1992. Resolução do CONAMA, $4^{\circ}$ edição, Brasilia, IBAMA.

Cowart J.B. \& Osmond J.K.I 974 . U234 and U-238 in the carrizo sandstone aquifer of south Texas - Isotope Techiniques in groundwater hydrology II - Proceedings of a symposium, IAEA, Vienna, pp. 131-149.

Ferreira F.J. F, Souza J.L., Rocha H.O., Mantovani L.E. 1997. Airborne gamma-ray spectrometry and remote sensing to map uranium acumulation in soils from longcontinued application of fertilizers in Araras region, Brazil. In: 12 International Conference Applied Geologic Remote Sensing, Denver, USA, 1:323-330.
IAEA - International Atomic Energy Agency 1991. International Symposium on the Use of Isotope Techniques in Water Resources Development. UNESCO, Vienna, $251 \mathrm{p}$.

Inacio A. \& Santos M.J.Z. 1988. Características climaticas de Rio Claro. Boletim de Geografia Teoretica, 18:87-104.

IPT - Institute de Pesquisa Tecnologica do Estado de São Paulo. 1981. Mapa Geológico do Estado de São Paulo. Monografias, São Paulo.

Langmuir D. 1978. Uranium solution-mineral equilibria at low temperatures with applications to sedimentary ore deposits. Geochim. Cosmoch. Acta, 42:547-569.

Koffler N.F. 1993. Diagnosticos do uso agrícola das terras da Bacia do Rio Corumbatai SP. Institute de Geociências e Ciências Exatas/UNESP, Relatorio, 102p.

Moreira-Nordemann L. M. 1979. Use of 234U/238U disequilibrium in measuring chemical weathering rate of rocks. Geochim. Cosmoch.Acta, 44:103-108

Palma-Silva G.M. 1999. Diagnostico amhiental, qualidade da água e indice de depurafdo do Rio Corubatai - SP. CEA (Centra de Estudos Ambientais), Universidade Estadual Paulista, Rio Claro, Dissertação de Mestrado, 155p

Penteado M.M. 1976. Geomorfologia do setor centro-ocidental da Depressão Periferica Paulista. Serie teses e monografias, ${ }^{\circ} 22$. IGEOG/USP, SP, 86p.

Porto FA., Franco S.M., Luca S.J. 1991. Estabelecimento dos parÂmetros de controle da poluição. In: EDUSP (ed) Hidrologia Amhiental.São Paulo, 375-390.

Tonetto E.M. 1996. O tório em águas subterrâneas de Aguas da Prata (SP). Institute de Geociências e Ciências Exatas, Universidade Estadual Paulista, Rio Clare, Disser13930 de Mestrado, $81 \mathrm{p}$
Contribution IGC-057 Received February 3,2000 Accepted for publication May 10, 2000 